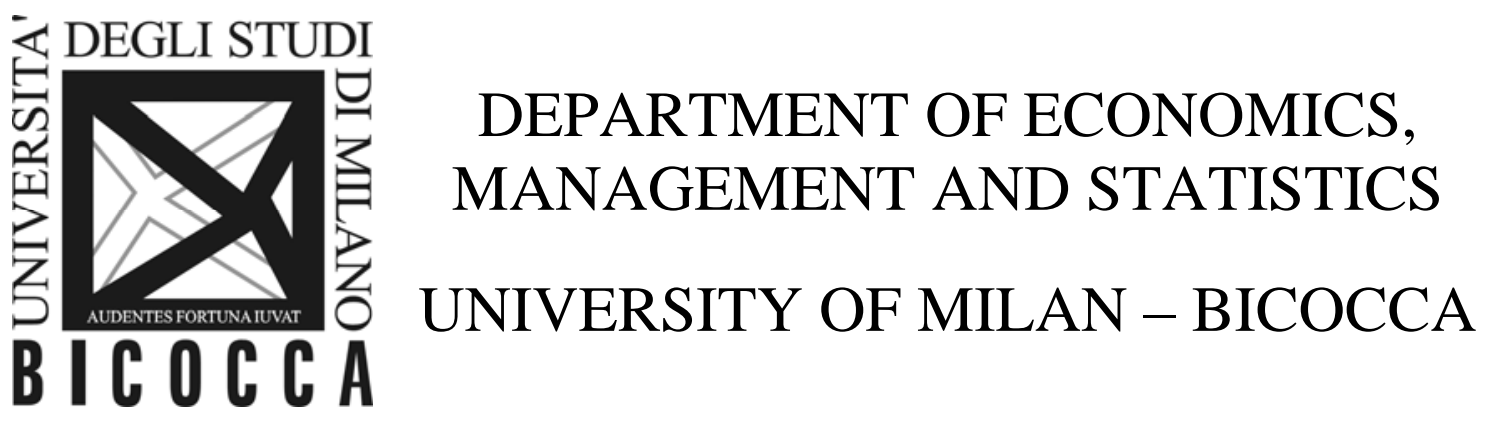

DEMS WORKING PAPER SERIES

\title{
Shadow economies at times of banking crises: empirics and theory
}

\author{
Emilio Colombo, Luisanna Onnis, \\ Patrizio Tirelli
}

No. 234 - February 2013

Dipartimento di Economia, Metodi Quantitativi e Strategie di Impresa Università degli Studi di Milano - Bicocca 


\title{
Shadow economies at times of banking crises: empirics and theory
}

\author{
Emilio Colombo* \\ UNIV. MILANO-BICOCCA \\ Luisanna Onnis \\ UNIV. MILANO-BICOCCA \\ Patrizio Tirelli \\ UNIV. MILANO-BICOCCA
}

February 2013

\begin{abstract}
This paper investigates the response of the shadow economy to banking crises. Our empirical analysis, based on a large sample of countries, suggests that the informal sector is a powerful buffer, which expands at times of banking crises and absorbs a large proportion of the fall in official output. To rationalise our evidence, we build a dynamic stochastic general equilibrium model which accounts for financial frictions and nominal rigidities. In line with the empirical literature on the shadow economy, we assume that in the informal sector access to external finance is limited, and the production technology is relatively more labour intensive. Following a banking shock in the official sector, the model predicts a large negative transmission to the unofficial economy: about $60 \%$ of the official sector contraction is absorbed by the growth of the shadow economy.
\end{abstract}

JEL: E26, E32, E44

Keywords: Financial crises, shadow economy, DSGE models

*Corresponding author: University of Milano-Bicocca Piazza Ateneo Nuovo 1, Edificio U6, 20126 Milano, Italy, e-mail: emilio.colombo@unimib.it. Ph: +390264483167 Fax: +390264483085 . We thank conference participants at Miami (PCS conference), Bocconi University and University of Venice for helpful comments. Lorenzo Menna provided outstanding research assistance. 


\section{Introduction}

Banking crises are typically associated with a prolonged decline in output and employment (Rajan and Zingales, 1998; Kroszner et al., 2007; Cerra and Saxena, 2008; Dell'Ariccia et al., 2008; Reinhart and Rogoff, 2009b). One less investigated issue is the contemporaneous behavior of the informal economy during such episodes. Recent contributions, suggesting that the relative size of the shadow economy might be on the rise in the aftermath of the 2007 crisis (Schneider and Buehn, 2012; Elgin and Oztunali, 2012), have found considerable echo in the press. ${ }^{1}$

Understanding the shadow economy adjustment to banking crises makes it possible to provide more effective estimates of the real costs of crises, both in terms of output and employment; in addition it has important policy implications. On the one hand, the existence of an informal sector may add resilience to the economy when times are hard. On the other hand, the erosion of the tax base greatly complicates the task of fiscal policy makers at a time of ballooning public deficits. In fact, revenue losses seem to be the main cause of the dramatic increase in debt-to-GDP ratios that typically follows the explosion of a banking crisis (Reinhart and Rogoff, 2009a).

This is the first paper which empirically and theoretically analyses the response of the shadow economy to the banking crisis. There are several macroeconomic methods for measuring the relative size of the shadow economy, all of which have shortcomings (Maloney and Saavedra-Chanduvi, 2005). For our purposes even the Multiple Indicator-Multiple Cause (MIMIC) approach, which is the most widely used, would be inappropriate because shadow economy data sets based on the MIMIC method, such as Schneider et al. (2010), are too limited in the time series dimension of the sample. We therefore take an alternative route, based on the assumption that the rate of change in electricity consumption is a proxy for the growth rate of Total Economic Activity (henceforth TEA). ${ }^{2}$ We thus take the differential

1 "A Lengthening Shadow" The Economist, August 2010 ; "Europe: Hidden economy", The Financial Times 8th June 2011; "Shadow economies all around the world: Modelbased estimates", Vox, available at http://www.voxeu.org

${ }^{2}$ Standard measures of the relative size of the shadow economy based on the electricity consumption method are probably biased because informal activities are less electricity intensive than formal activities and because it is difficult to take into account energy-saving technological change (Schneider and Enste, 2000; La Porta and Shleifer, 2008). Neither criticism applies here. Our methodology does not require any information about the size of the shadow economy and the obtained responses to crisis episodes are unlikely to be 
responses of TEA and official output growth rates to banking crises as a broad indicator of shadow economy dynamics.

We find that the TEA fall is very small relative to what we observe for the official output. Further, the TEA drop is never statistically significant if we control for variations in the relative price of electricity and for sectoral output composition in the official economy, as in Eilat and Zinnes (2002) and Onnis and Tirelli (2010). By contrast, we show that financial crises are followed by a deep contraction of gross capital formation. This implies an increase in the electricity-consumption-to-GDP ratio which is particularly striking in light of the huge literature on the procyclical pattern of electricity consumption. In fact electricity consumption is used as a proxy for capacity utilisation in business cycle models (Bils and Cho, 1994; Comin and Gertler, 2006), and as a leading indicator for business cycle conditions (Marchetti and Parigi, 2000; Kamada and Masuda, 2001).

Although the cyclical pattern of the unofficial economy cannot be directly observed, this evidence indicates a potentially large shadow economy increase in response to financial crises. To rationalise our empirical results, we build a two-sector DSGE model which accounts for price stickiness and for credit market frictions. Our characterisation of the shadow economy is consistent with two "stylised facts". The first is that firms operating in the shadow economy have access to a relatively more labour intensive production technology (Amaral and Quintin, 2006; Koreshkova, 2006). The second is that formal and informal financial sectors coexist and are characterised by different degrees of efficiency in channelling funds from households to firms. Moreover, it is well known that the access of informal firms to outside finance is typically limited (Banerjee and Duflo, 2007; Madestam, 2008; Batini et al., 2011).

Following a banking shock in the official sector, our model predicts a disruption of capital formation in the official economy. This, in turn, is associated with a fall in official output and employment. The ensuing real wage fall favours an increase in output and employment in the unofficial economy. The sectoral reallocation of employment causes a persistent increase in the marginal productivity of capital in the unofficial sector, and triggers a surge in unofficial investment. We obtain a large negative transmission effect: about $60 \%$ of the official sector contraction is absorbed by the growth of the shadow sector.

affected by the imprecise measurement of long run technical change. 
Previous empirical evidence on the cyclical pattern of the shadow economy is mixed. Bajada (2003) and Giles (1997) find a procyclical relationship in Australia and New Zealand, respectively. A number of studies based on the MIMIC approach support the view that the shadow economy acts as a buffer, increasing its size in periods of recession (Bajada and Schneider, 2005; Schneider and Enste, 2000; Feld and Schneider, 2010). Russo (2008) obtains a similar result for the US using the electricity consumption and currency demand approaches. Our theoretical results do not fully confirm this view. In fact we find that technology shocks induce a positive correlation between sectoral outputs. Thus our model does not merely predict a countercyclical behaviour of the underground economy; on the contrary, it highlights a propagation pattern which is specific to financial shocks.

Our theoretical contribution adds to a small but rapidly expanding literature. Business cycle models of the informal economy basically fall into two categories. In the first there are real business cycle models that incorporate an informal sector (Conesa Roca et al., 2001; Busato and Chiarini, 2004; Granda-Carvajal, 2010). In the second there are models that focus on the labour market, assuming either search frictions (Bosch and EstebanPretel, 2012) or the dual labour market hypothesis (Fiess et al., 2010). These two alternative assumptions about the functioning of the labour market are central in the DSGE models respectively presented in Castillo and Montoro (2010) and Mattesini and Rossi (2009). None of these contributions incorporates financial frictions as important elements of business cycle fluctuations and the inter-sectoral transmission of shocks as we do in this paper. The only exception is Batini et al. (2011). Our paper differs from theirs in two key aspects: the first is the modelling strategy of financial frictions that we derive endogenously, while they assume an exogenous external finance premium; the second is the focus on banking shocks, which are neglected in their contribution.

The remainder of the paper is structured as follows. Section 2 describes the data and methodology used in the empirical analysis. Section 3 presents the empirical results. Section 4 describes the theoretical model and illustrates the findings. Section 5 concludes. 


\section{Data and methodology}

\subsection{Measuring banking crises and Total Economic Ac- tivity}

Defining banking crises is often controversial, due to the lack of a consensual definition and the need of a certain degree of discretionary judgement. We adopt the well known classification by Laeven and Valencia (2010, 2008), who focus on systemic banking crises excluding distress events that affected isolated banks. ${ }^{3}$

We consider two measures of the growth of total economic activity. The first one is the growth rate of electricity consumption $T E A g$. The second one $(M T E A g)$ is obtained filtering $T E A g$ to remove the effects of variations in the relative price of electricity and of sectoral output composition in the official economy (Eilat and Zinnes, 2002; Onnis and Tirelli, 2010). The Appendix describes in greater detail the procedure used to construct these variables.

\subsection{Methodology}

Our methodology for identifying the effects of banking crises follows Cerra and Saxena (2008), who in turn draw on the influential work by Romer and Romer (1989). ${ }^{4}$ We estimate the following autoregressive model:

$$
\Delta Y_{i, t}=\alpha_{i}+\sum_{s=1}^{4} \beta \Delta Y_{i, t-s}+\sum_{s=0}^{3} \gamma D F C_{i, t-s}+\epsilon_{i, t}
$$

where $\Delta Y=T E A g, M T E A g$ is the growth rate of the total economy, $D F C$ is a dummy variable for the presence of a financial crisis, and $i$ is a country index. The number of lags of both the dependent variable and

\footnotetext{
${ }^{3}$ More precisely the starting year of the crises is identified by a) deposit runs, defined as a monthly percentage decline in deposits in excess of 5 percent, b) the introduction of deposit freezes or blanket guarantees, and c) liquidity support or central bank interventions, defined as the ratio of monetary authorities' claims on banks as a fraction of total deposits of "at least $5 \%$ and at least double the ratio compared to the previous year".

${ }^{4}$ See also Romer and Romer (2010) for a more recent analysis of the impact of fiscal shocks.
} 
the crisis dummy have been chosen to maximise the informativeness of the model. $^{5}$

We estimate (1) using panel data that control for the presence of fixed effects, and allow for heteroskedasticity of the error term and for autocorrelation within groups (countries).

Impulse response function and $95 \%$ confidence bands are obtained from 1000 Monte Carlo simulations (see the Appendix).

\section{Empirical results}

Figure 1 shows the effect of banking crises on official GDP and on TEA. The measured impact of banking crises on GDP confirms previous results (Cerra and Saxena, 2008). ${ }^{6}$ Crisis episodes have a long lasting and permanent effect on GDP, and the fall in official investment (which is the most energyintensive component of aggregate demand) is even stronger (about 15\%, not reported in the figures). Results are strikingly different when the analysis is replicated for the growth of total economic activity. The TEA drop is very limited, suggesting a potentially strong role of the shadow economy as a shock absorber in response to the crisis. Further, the response of $M T E A$ is never significant (Figure 2). These results are confirmed when we split the sample into different subgroups following a per-capita income criterion.

Adding time dummies allows us to check whether crises reflect some other global shock common to all countries. The first row of Figure 3 shows that the results are unchanged. In addition we tested whether our results are driven by some extreme values. The second row of Figure 3 shows impulse responses excluding possible outliers in growth rates of total economic activity. Also in this case our benchmark estimates are confirmed.

We based our analysis on the implicit assumption that financial crises are exogenous to the growth of total economic activity. To control for potential endogeneity we implemented two tests. First, we estimated the model excluding the contemporaneous effect of the crisis on total output growth. The third line of Figure 3 illustrates the result showing that nothing changes. Second, we predicted financial crises with current and lagged values of the

\footnotetext{
${ }^{5}$ The four-year time lag is consistent with the literature estimating output responses at the same or at higher frequencies (Cerra and Saxena, 2008).

${ }^{6}$ With respect to Cerra and Saxena (2008) our impulse responses show a slightly lower output drop due to the fact that our sample is shorter.
} 
relevant variable growth rate, using a logit model. Table 4 shows that neither $T E A$ nor $M T E A$ help to forecast financial crises (on the contrary there is a significant negative relationship between DGP growth and crises). Repeating the same exercise without the contemporaneous effect yields identical results.

\section{Financial frictions and the shadow econ- omy in a DSGE model}

Dual credit markets models assume that the informal financial sector is relatively less efficient, thus generating in the shadow economy a relative scarcity of capital and greater reliance of entrepreneurs on self-financing (Straub, 2005; Pratap and Quintin, 2006; Antunes et al., 2008). The bulk of existing empirical evidence emphasises that informal financing is based on relationship lending ("mafia protection", informal credit by money lenders, etc.) which is less transparent and efficient in credit provision with respect to official credit markets, but also relatively more efficiently in monitoring and enforcing repayment from small firms. Contrary to common wisdom, some contributions suggest that informal credit markets do not always prevent rapid economic expansion. According to Besley and Levenson (1996) Taiwan's fast growth greatly benefited from informal financial institutions. More recently several studies have shown a similar role for Chinese informal financial institutions (Allen et al., 2005, 2012; Ayyagari et al., 2010). Finally, some studies have documented the importance played by informal financial networks even in developed countries such as Italy (Guiso et al., 2004) and the US (Garmaise and Moskowitz, 2003).

Incorporating all these aspects within a theoretical framework is not straightforward. Our approach is build a fairly standard DSGE model to to account for both the official $(o)$ and the underground $(s)$ sectors of the economy. A crucial role is played by the credit market, where we adopt the standard framework of the agency cost approach pioneered by Bernanke and Gertler (1989) and developed by Carlstrom and Fuerst (1997) - henceforth $\mathrm{C}-\mathrm{F}$ - which we will follow closely.

A fraction $\eta$ of the population - the entrepreneurs - have the ability to transform $i$ consumption goods into $i \omega$ capital goods, where $\omega$ is a random variable subject to idiosyncratic shocks. $\omega$ realisations are entrepreneur's private information, generating standard agency issues. A fraction $\eta^{o}$ of en- 
trepreneurs operates in the official sector, the rest in the shadow economy. In each sector a capital mutual fund or "bank" $\left(\mathrm{CMF}^{j}, j=o, s\right)$ collects funds from the common pool of household savings and lends them to entrepreneurs. $^{7}$

We depart from $\mathrm{C}-\mathrm{F}$ in assuming that financial operations are costly: they entail a dissipation of resources, and are relatively larger in the informal sector. This allows us to delineate a situation where the financial sector of the shadow economy is relatively inefficient, i.e. unofficial economy entrepreneurs earn a relatively smaller proportion of investment proceeds, and the fraction of external financing in this sector is relatively limited. ${ }^{8}$

With respect to recent contributions such as Gertler et al. (2011), our characterisation of the financial market is admittedly crude in order to provide a satisfactory description of the banking sector in a general equilibrium framework. Nevertheless, it captures a key mechanism that drives the transmission of bank crises to the shadow economy, i.e. the large and persistent disruption to the process of capital accumulation in the official economy documented in section 3 .

In both sectors perfectly competitive firms produce wholesale goods which are then sold to monopolistically competitive retail firms. Retail prices are sticky. We assume a perfectly competitive labour market, in line with Amaral and Quintin (2006) and Pratap and Quintin (2006). ${ }^{9}$

The sequence of events is standard from C-F.

- Wholesale firms hire labor and capital from households and entrepreneurs to produce consumption goods. Retail firms differentiate goods and adjust consumption prices. Firms choices are conditional to productivity shocks and to the monetary policy rule.

- Households choose consumption and the allocation of investment to financial intermediaries.

\footnotetext{
${ }^{7}$ Several studies document that funds originating in the official economy are then intermediated in the informal financial market and channelled into the unofficial sector of the economy (Conning and Udry (2007), Madestam (2008) and the studies cited therein).

${ }^{8}$ De Soto (2000) forcefully argues that informal assets are much more difficult to leverage into loans than assets belonging to entrepreneurs operating in the official sector.

${ }^{9}$ This assumption is supported by Maloney $(1999,2004)$ and Pratap and Quintin (2006) who provide evidence against labor market segmentation. Another strand of literature emphasises the role of search frictions in shaping occupational choices between the two sectors (see Batini et al., 2011 for a survey). We retain the competitive labor market hypothesis in order to sharpen our focus on credit frictions.
} 
- CMFs lend consumption goods to entrepreneurs.

- Entrepreneurs use borrowed and own resources to create capital.

- The idiosyncratic shock of each entrepreneur is realised and the debt contract is enforced. Proceeds from creation of new investment goods are then split between households and entrepreneurs.

- Entrepreneurs choose their consumption.

In the model the inter-sectoral transmission of shocks typically occurs through flows in the factor services across the two sectors, driven by arbitrage conditions in the capital and labour markets. ${ }^{10}$

\subsection{Firms}

In each sector $j(o, s)$, perfectly competitive (flex-price) firms produce wholesale goods $I j$ and sell them to retail producers $R j$ that introduce product differentiation and are subject to price rigidity.

Household preferences over the goods produced in the economy are defined as follows. The CES consumption bundle, $c_{t}$, is:

$$
c_{t}=\left[\left(1-\alpha_{c}\right)^{\frac{1}{\varepsilon}}\left(c_{t}^{o}\right)^{\frac{\epsilon-1}{\varepsilon}}+\left(\alpha_{c}\right)^{\frac{1}{\varepsilon}}\left(c_{t}^{s}\right)^{\frac{\epsilon-1}{\varepsilon}}\right]^{\frac{\varepsilon}{\varepsilon-1}}
$$

Further, each $c_{t}^{j}$ is also defined as a $C E S$ bundle.

$$
c_{t}^{j}=\left(\int_{0}^{1} c_{t}^{j}\left(z^{j}\right)^{\frac{\sigma^{j}-1}{\sigma^{j}}} d z^{j}\right)^{\frac{\sigma^{j}}{\sigma^{j}-1}}
$$

Parameter $\varepsilon>1$ measures the elasticity of substitution between the official and the shadow consumption bundles $c_{t}^{o}$ and $c_{t}^{s}$, whereas $\sigma^{j}>1$ measures the elasticity of substitution among the differentiated goods that form $c_{t}^{j}$.

Demand functions for individual goods within each consumption bundle are:

$$
c_{t}^{j}\left(z^{j}\right)=\left(\frac{P_{t}^{R j}\left(z^{j}\right)}{P_{t}^{R j}}\right)^{-\sigma^{j}} c_{t}^{j}
$$

\footnotetext{
${ }^{10}$ Assumptions about the steady state size of entrepreneurs and firms in the two sectors are just innocuous normalisations as long as we allow for capital and labour intersectoral flows For sake of simplicity we do not consider flows of firms, and entrepreneurs, between the two sectors over the business cycle.
} 
where:

$$
\begin{gathered}
P_{t}^{R j}=\left(\int_{0}^{1}\left(P_{t}^{R j}(z)\right)^{1-\sigma^{j}} d z\right)^{\frac{1}{1-\sigma^{j}}} \\
c_{t}^{o}=\left(1-\alpha_{c}\right)\left(\frac{P_{t}^{R o}}{P_{t}}\right)^{-\varepsilon} c \\
c_{t}^{s}=\alpha_{c}\left(\frac{P_{t}^{R s}}{P_{t}}\right)^{-\varepsilon} c \\
P_{t}=\left(\left(1-\alpha_{c}\right)\left(P_{t}^{R o}\right)^{(1-\varepsilon)}+\alpha_{c}\left(P_{t}^{R s}\right)^{(1-\varepsilon)}\right)^{\frac{1}{(1-\varepsilon)}}
\end{gathered}
$$

respectively define the sectoral retail price index, the demand functions for the sectoral bundles and the consumption price index.

\subsubsection{Wholesale producers}

Wholesale producers have access to the production technology:

$$
y_{t}^{j}=\left(\exp \theta_{t}^{j}\right)\left(k_{t}^{j}\right)^{\alpha^{j}}\left(h_{t}^{j}\right)^{1-\alpha^{j}}
$$

where $y_{t}^{j}, k_{t}^{j}, h_{t}^{j}$ respectively define sector-specific output, capital and labour and $\theta_{t}^{j}$ captures sectoral productivity shocks, which displays the following time path:

$$
\theta_{t}^{o}=\rho^{\theta} \theta_{t-1}^{o}+\xi_{t}^{o} ; \quad \xi_{t}^{o} \text { i.i.d. }
$$

Factor demands are:

$$
\begin{gathered}
\frac{P_{t}}{P_{t}^{I j}} w_{t}=\left(1-\alpha^{j}\right) \theta_{t}^{j}\left(\frac{k_{t}^{j}}{h_{t}^{j}}\right)^{\alpha^{j}} \\
r_{t}^{j}=\alpha^{j} \theta_{t}^{j}\left(\frac{k_{t}^{j}}{h_{t}^{j}}\right)^{-\left(1-\alpha^{j}\right)}
\end{gathered}
$$

where $w_{t}, P_{t}, P_{t}^{I j}, r_{t}^{j}$ respectively define the real consumption wage rate, the consumption price index, the sectoral price index for intermediate goods and the sectoral real return on capital. Intermediate sector real marginal costs, $m c_{t}^{I j}$, are:

$$
m c_{t}^{I, j}=\left(\frac{r_{t}^{j}}{\alpha^{j}}\right)^{\alpha^{j}}\left(\frac{\frac{P_{t}}{P_{t}^{I j}} w_{t}}{\left(1-\alpha^{j}\right)}\right)^{1-\alpha^{j}}
$$


Sectoral intermediate prices equal nominal marginal costs:

$$
\begin{aligned}
& P_{t}^{I, j}=\left(\frac{P_{t}^{I, j} r_{t}^{j}}{\alpha^{j}}\right)^{\alpha^{j}}\left(\frac{P_{t} w_{t}}{\left(1-\alpha^{j}\right)}\right)^{1-\alpha^{j}} \\
& P_{t}^{I, j}=\left(\frac{r_{t}^{j}}{\alpha^{j}}\right)^{\frac{\alpha^{j}}{1-\alpha^{j}}}\left(\frac{P_{t} w_{t}}{\left(1-\alpha^{j}\right)}\right)
\end{aligned}
$$

\subsubsection{Retail producers}

We assume a sticky price specification based on Rotemberg (1982) quadratic cost of nominal price adjustment:

$$
\frac{\varphi}{2}\left(\frac{P_{t}^{R j}(z) / P_{t-1}^{R j}(z)}{\left(\pi_{t-1}^{R j}\right)^{\delta_{\pi}}}-1\right)^{2}
$$

where $\varphi \geq 0$ is a measure of price stickiness, $\pi_{t}^{R j}=\frac{P_{t}^{R j}}{P_{t-1}^{R j}}$ denotes the sectoral gross inflation rate and $\delta_{\pi}$ is a price indexation parameter.

In a symmetrical equilibrium the price adjustment rule satisfies:

$$
\begin{array}{r}
\left(\frac{\left(1-\sigma^{j}\right)}{\sigma^{j}}+\frac{P_{t}^{I j}}{P_{t}^{R j}}\right) \frac{\sigma^{j}}{\varphi}+\beta\left[\left(\frac{\lambda_{t+s}}{\lambda_{t}}\right) \frac{y_{t+1}^{j}}{y_{t}^{j}}\left(\frac{\pi_{t+1}^{R j}}{\left(\pi_{t}^{R j}\right)^{\delta_{\pi}}}-1\right)\left(\frac{\pi_{t+1}^{R j}}{\left(\pi_{t}^{R j}\right)^{\delta_{\pi}}}\right)\right] \\
=\left(\frac{\pi_{t}^{R j}}{\left(\pi_{t-1}^{R j}\right)^{\delta_{\pi}}}-1\right) \frac{\pi_{t}^{R j}}{\left(\pi_{t-1}^{R j}\right)^{\delta_{\pi}}}
\end{array}
$$

wnere $\frac{P_{t}^{I j}}{P_{t}^{R j}}$ defines real marginal costs in terms of the sectoral retail price. Consumption price inflation is:

$$
\pi_{t}=\frac{P_{t}}{P_{t-1}}
$$




\subsection{Households}

Households are characterised by a standard utility function

$$
U_{t}^{i}=E_{t} \sum_{k=o}^{\infty} \beta^{k}\left\{\ln \left(c_{t+k}^{i}-b c_{t+k-1}\right)-\frac{\psi}{1+\phi}\left(h_{t+k}\right)^{1+\phi}\right\}
$$

which accounts for external habits. ${ }^{11}$.

The intertemporal Euler equation is ${ }^{12}$

$$
\lambda_{t}=\beta \lambda_{t+1} \frac{R_{t}}{\pi_{t+1}}
$$

where $R_{t}$ is the interest rate paid on a nominally riskless bond and

$$
\lambda_{t}=\frac{1}{c_{t}-b c_{t-1}}
$$

is the marginal utility of the consumption bundle.

In the competitive labour market, the standard labour supply condition holds:

$$
\frac{\psi\left(h_{t}\right)^{\phi}}{\lambda_{t}}=w_{t}
$$

where $w_{t}$ is the wage rate in units of the consumption bundle. For each sector $j$, households capital demand is driven by:

$$
q_{t}^{j}=\beta \frac{\lambda_{t+1}}{\lambda_{t}}\left[q_{t+1}^{j}(1-\delta)+r_{t+1}^{j}\right]
$$

and $r_{t+1}^{j}$ defines the return that firms pay on borrowed capital goods.

\subsection{The financial contract}

In each sector the financial contract is stipulated between a risk-neutral entrepreneur endowed with financial wealth $n_{t}^{j}$, and the sectoral $\mathrm{CMF}^{j}$. Following the costly state verification approach, information about the entrepreneurspecific $\omega$ realisations becomes available to the $\mathrm{CMF}^{j}$ at the monitoring cost

\footnotetext{
${ }^{11}$ The habit assumption is fairly standard in the literature (see Wouters and Smets, 2005)

${ }^{12}$ For sake of simplicity we drop superscripts $i$
} 
$\mu^{j}$. Here we make the additional assumptions that: i) for every funding project, the $\mathrm{CMF}^{j}$ is subject to a cost $\chi^{j} i_{t}^{j}$; ii) when entering the the borrowing relationship, the entrepreneur is subject to a cost $\kappa^{j} n_{t}^{j}$. These two assumptions will be used to characterise differences in the use of external finance across sectors.

The entrepreneur borrows $\left(i^{j}-\left(1-\kappa^{j}\right) n^{j}\right)$ and agrees to repay the loan at the gross rate $\left(1+r^{k}\right)$; it is assumed for simplicity that $r^{k}=0$ since CMF funding is intra-period. This implies that all rents accrue to entrepreneurs, net of the CMFs operational costs. To preserve the simplicity and tractability of the model, we assume that an entrepreneurs "union" is assigned the task of collecting individual contributions necessary to finance $\chi^{j}$.

The contract is also defined by the pair $\left(i^{j}, \widetilde{\omega}^{j}\right)$ that maximises the entrepreneur's expected income subject to the CMF being indifferent between lending or retaining the funds. Note that $\widetilde{\omega}^{j}$ defines both the default threshold and the payment rate accruing to the lender from non-defaulting entrepreneurs. When $\omega<\widetilde{\omega}^{j}$ default occurs and the lender monitors. We assume that idiosyncratic productivity shocks are uniformly distributed with support $[\bar{\omega}, \underline{\omega}]$, and that defaulting entrepreneurs retain the fixed amount $\underline{\omega}$, so that in the next period they can borrow again. ${ }^{13}$ Therefore $\mathrm{CMF}^{j}$ proceeds from shock realisations $\omega<\widetilde{\omega}^{j}$ amount to $\omega-\left(\mu^{j}+\underline{\omega}\right)$.

Finally, we define the entrepreneur contribution scheme necessary to ensure that CMFs operational costs are covered. i) only non-defaulting entrepreneurs contribute a fraction of the proceeds from their investment $i^{j} \omega$; ii) the individual contribution of non-defaulting entrepreneurs is $\bar{\chi}^{j}$ unless the entrepreneur is characterised by shock realisations $\widetilde{\omega}^{j}<\omega<\widetilde{\omega}^{j}+\bar{\chi}^{j}+\underline{\omega}$. In this latter case the contribution amounts to $\max \left\{0, \omega-\left(\underline{\omega}+\widetilde{\omega}^{j}\right)\right\}$ and the entrepreneur retains the amount $\underline{\omega}$ which allows him to borrow again in the next period. ${ }^{14}$

The optimal contract maximises $q_{t}^{j} i_{t}^{j} f\left(\widetilde{\omega}_{t}^{j}\right)$ subject to $q_{t}^{j} i_{t}^{j} g\left(\widetilde{\omega}^{j}\right) \geq\left(i_{t}^{j}-\right.$ $\left(1-\kappa^{j}\right) n_{t}^{j}$, where $q_{t}^{j}$ defines sector $j$ consumption price of capital, and

\footnotetext{
${ }^{13}$ In fact it is well known that the financial contract is not well defined when the borrower's net worth is zero. An alternative assumption would be to have entrepreneurs supply their labour to firms, as in C-F.

${ }^{14}$ It would be straightforward to show that this characterisation of the contribution scheme allows us to preserve in our context the optimality of the simple contract defined in $\mathrm{C}-\mathrm{F}$.
} 


$$
\begin{aligned}
& f\left(\widetilde{\omega}_{t}^{j}\right)=\phi\left(\frac{\bar{\omega}^{2}}{2}-\frac{\widetilde{\omega}_{t}^{j 2}}{2}\right)-\phi\left(\bar{\omega}-\widetilde{\omega}_{t}^{j}\right) \widetilde{\omega}_{t}^{j}+\phi\left(\widetilde{\omega}_{t}^{j}-\underline{\omega}\right) \underline{\omega}-\chi_{t}^{j} \\
& g\left(\widetilde{\omega}_{t}^{j}\right)=\phi\left(\bar{\omega}-\widetilde{\omega}_{t}^{j}\right) \widetilde{\omega}_{t}^{j}+\phi\left(\frac{\widetilde{\omega}_{t}^{j 2}}{2}-\frac{\underline{\omega}^{2}}{2}\right)-\phi\left(\widetilde{\omega}_{t}^{j}-\underline{\omega}\right)\left(\mu^{j}+\underline{\omega}\right)
\end{aligned}
$$

respectively define the investment shares ${ }^{15}$ accruing to the entrepreneur and to the $\mathrm{CMF}^{j}{ }^{16}$ Note that we set

$$
\begin{gathered}
\chi_{t}^{s}=\chi^{s} \\
\chi_{t}^{o}=\chi^{o} \exp \left(v_{t}^{\chi}\right)
\end{gathered}
$$

where

$$
v_{t}^{\chi}=\rho^{\chi} v_{t-1}^{\chi}+\xi_{t}^{\chi} ; \xi_{t}^{\chi} \text { i.i.d. }
$$

defines the financial shock to the official sector.

Formally, the contract is defined by the following first order conditions:

$$
\begin{gathered}
i_{t}^{j}=\frac{\left(1-\kappa^{j}\right) n_{t}^{j}}{1-q_{t}^{j} g\left(\widetilde{\omega}_{t}^{j}\right)} \\
q_{t}^{j}\left\{1-\phi\left(\widetilde{\omega}_{t}^{j}-\underline{\omega}\right)\left(\mu^{j}\right)+\phi \mu^{j} \frac{f\left(\widetilde{\omega}_{t}^{j}\right)}{f^{\prime}\left(\widetilde{\omega}_{t}^{j}\right)}\right\}=1
\end{gathered}
$$

where

$$
f^{\prime}\left(\widetilde{\omega}_{t}^{j}\right)=-\phi\left(\bar{\omega}-\widetilde{\omega}_{t}^{j}\right)+\phi \underline{\omega}
$$

For any given $q_{t}^{j}$, conditions (21), (22) identify the default threshold and the amount of investment, ${ }^{17}$ where term $\frac{\left(1-\kappa^{j}\right)}{1-q_{t}^{j} g\left(\widetilde{\omega}_{t}^{j}\right)}$ is the leverage ratio.

\footnotetext{
${ }^{15}$ The fixed cost $\chi^{j}$ reduces rents, which are entirely appropriated by the entrepreneur. ${ }^{16}$ The term $\phi=(\bar{\omega}-\underline{\omega})^{-1}$ defines the density of the distribution.

${ }^{17}$ As shown in C-F, condition (21) denotes both individual and aggregate investment decisions.
} 


\subsection{Entrepreneurs}

Risk-neutral entrepreneurs, characterised by superscript $e$, maximise:

$$
U_{t}^{e, j}=E_{t} \sum_{k=o}^{\infty}(\beta \gamma)^{k} c_{t+k}^{e, j}
$$

where $c^{e, j}$ is defined over the consumption bundle. In each sector, entrepreneurs demand for firms capital is

$$
q_{t}^{j}=\beta \gamma\left[q_{t+1}^{j}(1-\delta)+r_{t+1}^{j}\right] \frac{\left(1-\kappa^{j}\right) q_{t+1}^{j} f\left(\widetilde{\omega}_{t+1}^{j}\right)}{1-q_{t+1}^{j} g\left(\widetilde{\omega}_{t+1}^{j}\right)}
$$

Note that the CMFs operating in the two sectors borrow from the same pool of households, and are therefore constrained to guarantee the same return:

$$
q_{t}^{s} g\left(\widetilde{\omega}_{t}^{s}\right)=q_{t}^{o} g\left(\widetilde{\omega}_{t}^{o}\right)
$$

From (21) and (25) it is easy to see that $\kappa^{s}>\kappa^{o}$ allows to obtain a less leveraged shadow economy. Further, from (15) and (24) we obtain

$$
\frac{q_{t+1}^{s}\left(1-\kappa^{s}\right) f\left(\widetilde{\omega}_{t+1}^{s}\right)}{1-q_{t+1}^{s} g\left(\widetilde{\omega}_{t+1}^{s}\right)}=\frac{q_{t+1}^{o}\left(1-\kappa^{o}\right) f\left(\widetilde{\omega}_{t+1}^{o}\right)}{1-q_{t+1}^{o} g\left(\widetilde{\omega}_{t+1}^{o}\right)} .
$$

Due to the identical preferences of the entrepreneurs operating in the two sectors and to the common pool of households' funds, the expected rate of return on the entrepreneurs' internal funds is unique.

\subsection{Capital accumulation}

Sectoral capital accumulation is driven by

$$
k_{t}^{j}=(1-\delta) k_{t-1}^{j}+\eta \eta^{j} i_{t}^{j}\left(1-\phi\left(\widetilde{\omega}_{t}^{j}-\underline{\omega}\right) \mu^{j}-\chi_{t}^{j}\right)
$$

where monitoring costs and CMFs operational costs $\chi^{j}$ provide a rationalization of investment adjustment costs. Our results will show that shocks to $\chi^{o}$ have powerful effects on capital accumulation and generate a large transmission effect to the unofficial sector.

Dynamics of average wealth of entrepreneurs in sector $j$ are:

$$
n_{t}^{j}=\left(q_{t}^{j}(1-\delta)+r_{t}^{j}\right)\left(n_{t-1}^{j} \frac{\left(1-\kappa^{j}\right) f\left(\widetilde{\omega}_{t-1}^{j}\right)}{1-q_{t-1}^{j} g\left(\widetilde{\omega}_{t-1}^{j}\right)}-\left(\frac{c_{t-1}^{e j}}{q_{t-1}^{j}}\right)\right)
$$




\subsection{Resource constraints}

In each sector the resource constraint is

$$
\begin{gathered}
\theta_{t}^{j}\left(k_{t}^{j}\right)^{\alpha_{j}}\left(h_{t}^{j}\right)^{1-\alpha_{j}}=\left(1-\alpha_{c}\right)\left(\frac{P_{t}^{j}}{P_{t}}\right)^{-\varepsilon} C_{t}^{*}+\eta \eta^{j}\left(i_{t}^{j}\right) \\
C_{t}^{*}=\left((1-\eta) c_{t}+\eta\left(\left(\eta^{s}\right) c_{t}^{e s}+\eta^{o} c_{t}^{e o}\right)\right.
\end{gathered}
$$

Finally, the labor resource constraint is

$$
h_{t}^{o}+h_{t}^{s}=(1-\eta) h_{t}
$$

\subsection{Monetary policy}

Monetary policy follows a standard Taylor rule augmented for nominal interest rate smoothing, and reacts to the inflation rate of the official consumption bundle. ${ }^{18}$

$$
\frac{R_{t}}{R}=\left(\pi_{t}^{R o}\right)^{\phi^{\pi} \rho^{R}}\left(\frac{R_{t-1}}{R}\right)^{\left(1-\rho^{R}\right)}
$$

\subsection{Calibration}

The empirical section shows that the response of total economic activity to banking crises is similar across different country groups irrespective of the fact that these are characterised by a great deal of heterogeneity in terms of the relative size of the shadow economy, $S H=\frac{y^{s}}{y^{o}}$. In order to match this empirical finding we have modelled two "prototype" economies: one characterised by a low share of the shadow economy $(S H=12 \%$ matches the average of advanced economies) and one characterised by a high share of the shadow economy ( $S H=47 \%$ a value common to several low income countries).

Parameters characterising the official economy and households preferences are fairly standard. The values chosen for the household subjective discount factor, $\beta$, the capital income share $\alpha^{o}$, the capital depreciation rate, $\delta$, the entrepreneurs fraction $\eta$ and the entrepreneurs subjective discount factor, $\gamma$,

\footnotetext{
${ }^{18}$ In our simulations we also experimented with a monetary policy feedback on the current official output gap finding that our key results are entirely confirmed. For reasons of space we do not report here the impulse response functions obtained under this policy rule.
} 
are as in C-F. From Wouters and Smets (2005) we take the consumption habit parameter $b=0.7$, the inverse of the Fritsch elasticity $\psi=2$, the degree of inflation indexation $\delta_{\pi}=1,{ }^{19}$ the Taylor rule parameters $\phi^{\pi}=1.5$ and $\rho^{R}=0.9$. The degree of price stickiness, $\varphi^{o}=4.37$, and the price-elasticity parameter $\sigma^{o}=1.2$ are taken from Schmitt-Grohe and Uribe (2004). The elasticity of substitution between official and shadow consumption bundles, is set at 1.5 as in Batini et al. (2011). Turning to firms operating in the shadow economy, to capture the relatively low capital intensity in their production function we have chosen the capital share parameter, $\alpha^{s}=0.28$, as in Koreshkova (2006); we have also assumed that firms operating in the unofficial retail sector have limited market power, $\sigma^{s}=20$. To the best of our knowledge, there is no evidence about nominal rigidities in the unofficial sector. We therefore take as benchmarks the values adopted for the degree of price stickiness and for inflation indexation in the official sector. ${ }^{20}$

Turning to the financial sector parameters, we set $E(\omega)=1, \sigma_{\omega}^{2}=$, $\underline{\omega}=0.01$. To capture the well known features that leverage is smaller in the unofficial sector we set $\kappa^{s}=0.1$ and $\kappa^{o}=0$, implying that leverage is $10 \%$ lower in the shadow economy sector. The relative inefficiency of the informal financial sector is obtained by setting $\chi^{o}=0.01$, and $\chi^{s}=$ 0.15. The monitoring cost in the official sector, $\mu^{o}$ is calibrated to obtain a bankruptcy rate $\frac{\left(\widetilde{\omega}_{t}^{j}-\underline{\omega}\right)}{(\bar{\omega}-\underline{\omega})}=0.03$. Obtaining direct estimates of monitoring costs or turnover rates in informal economies is very difficult. Straub (2005) argues that monitoring costs are probably lower in informal sectors, but contract enforcement is probably easier. Since we have already modelled the relative inefficiency of the shadow economy financial sector, we opted for $\mu^{s}=\mu^{o}$. The preference parameters $\psi$ is set to obtain $h=1$ in steady state. Finally we close the model by calibrating $\alpha_{c}$ at the values consistent with the two alternative shares of the unofficial economy, $(S H=0.47 ; 0.12){ }^{21}$

\footnotetext{
${ }^{19}$ As a matter of fact Wouters and Smets adopt a more complex indexation scheme, but we replicate their assumption that the long-run Phillips curve is vertical.

${ }^{20} \mathrm{On}$ theoretical grounds it is not obvious that the proportional output cost associated to price revisions should be different across the two sectors. We also experimented with $\varphi^{s}=2.18$, and our results were entirely confirmed.

${ }^{21}$ The complete derivation of the steady state is reported in the Appendix.
} 
In the Appendix we show that in steady state

$$
\begin{gathered}
S H=\frac{\alpha_{c}}{\left(1-\alpha_{c}\right)}\left(\frac{P^{R s}}{P^{R o}}\right)^{-\varepsilon} \frac{\left(1-\frac{i^{o}}{y^{o}}\right)}{\left(1-\frac{i^{s}}{y^{s}}\right)}= \\
=\frac{\alpha_{c}}{\left(1-\alpha_{c}\right)}\left(\frac{\frac{\sigma^{o}}{\sigma^{o}-1}\left(\frac{q^{o}\left(\frac{1}{\beta}-(1-\delta)\right)}{\alpha^{o}}\right)^{\frac{\alpha^{o}}{1-\alpha^{o}}}}{\frac{\sigma^{s}}{\sigma^{s}-1}\left(\frac{q^{s}\left(\frac{1}{\beta}-(1-\delta)\right)}{\alpha^{s}}\right)^{\frac{\alpha^{s}}{1-\alpha^{s}}}}\left(\frac{\left(1-\alpha^{s}\right)}{\left(1-\alpha^{o}\right)}\right)\right)^{\varepsilon} \frac{\left(1-\frac{\delta}{\left(1-\phi\left(\widetilde{\omega}^{o}-\underline{\omega}\right) \mu^{o}-\chi^{o}\right)}\left(\frac{q^{o}\left(\frac{1}{\beta}-(1-\delta)\right)}{\alpha^{o}}\right)\right)}{\left(1-\frac{\delta}{\left(1-\phi\left(\widetilde{\omega}^{s}-\underline{\omega}\right) \mu^{s}-\chi^{s}\right)}\left(\frac{q^{s}\left(\frac{1}{\beta}-(1-\delta)\right)}{\alpha^{s}}\right)\right)}
\end{gathered}
$$

where

$$
q^{o}=\frac{1}{\left(f\left(\widetilde{\omega}^{o}\right) \gamma+g\left(\widetilde{\omega}^{o}\right)\right)}
$$

and

$$
q^{s}=\frac{\left(1-\kappa^{o}\right) f\left(\widetilde{\omega}^{o}\right)}{\left(1-\kappa^{s}\right) f\left(\widetilde{\omega}^{s}\right)} q^{o}
$$

The solution for $S H$ highlights the importance of the substitutability between official and unofficial goods, i.e. parameter $\varepsilon$, technology parameters $\alpha^{j}$, relative markups and the sectoral investment-to-output shares. In Table 2 we report the sensitivity of $S H$ to changes in these parameters starting from the two parameterisations for $\alpha_{c}$ that deliver high and low values for $S H$. An increase in unofficial retail price markups unambiguously reduces the unofficial sector supply. In fact, raising $\sigma^{s}$ to the official economy level lowers $S H$ by about $\frac{1}{5}$. An almost identical result is obtained if we impose strong substitutability between the official and the shadow consumption bundles, $\varepsilon=100$. Note that relative prices are entirely determined by supply-side effects, namely financial frictions, markups and technology parameters. In our benchmark calibration, for the high and low values of $S H$ we get $\frac{P^{R s}}{P^{R o}}=$ 1.19 and $\frac{q^{s}}{q^{o}}=1.01$ respectively. In spite of larger markups, the price of unofficial goods is always relatively high due to the higher cost of capital, determined by financial frictions, and to technology parameters. From (37) we know that consumption real wages do not matter for the determination of relative prices, but technology parameter $\alpha^{s}$ greatly strengthens the adverse effect of the relatively higher price of capital in the unofficial sector. In fact, when we set $\alpha^{s}=\alpha^{o}=0.36$ the value of $S H$ nearly doubles. To assess the consequences of financial factors, we lower both $\chi^{s}$ and $\kappa^{s}$ to the values 
chosen for the official economy. ${ }^{22}$ We find that only the fall in $\chi^{s}$ seem to matter, determining a $10 \%$ increase in $S H .{ }^{23}$

\subsubsection{Model dynamics and intersectoral transmission}

Figures 4-5 report the IRFs to the financial shock defined in equation (20). It is easy to see that the shock is followed by a sharp reduction in official investment, which drives the official output and employment fall. The model predicts a strong reduction in the nominal and real interest rates and a relatively large increase in the risk premium, $\frac{q_{t+1}^{o} f\left(\widetilde{\omega}_{t+1}^{o}\right)}{1-q_{t+1}^{o} g\left(\widetilde{\omega}_{t+1}^{j}\right)}-\frac{R_{t}}{\pi_{t+1}}$, a phenomenon typically associated to financial crises. The informal sector benefits from the reduction in real interest rates and wages. In fact informal investment output and employment increase in spite of the lower relative price of official sector goods. The informal sector expansion appears very effective in cushioning the negative impact of the financial shock: total output reduction is $60 \%$ lower than the official output fall. This result is obtained irrespective of the steady state share of the informal sector. For a better understanding of the transmission mechanism, we implemented a sensitivity analysis on some key parameters. We found that the total output loss has a moderate increase if official and unofficial goods are close substitutes $(\varepsilon=100)$ and if retail prices are flexible. This is intuitively plausible, because price flexibility and goods substitutability tilt demand towards official sector goods. By contrast, when we raised the capital income share in the unofficial sector $\left(\alpha^{s}=\alpha^{o}\right)$ we observed a dramatic increase in the response of unofficial labour demand after the initial wage fall. As a result the total output loss became negligible. Our simulations show that neither the sign nor the amplitude of the transmission mechanism in response to banking shocks depends on the relative size of $\kappa^{s}$, $\mu^{s}$ and $\chi^{s} .{ }^{24}$

The model is therefore able to predict a large cushioning effect of the shadow economy of a credit market shock hitting the official economy. Moreover this effect is very strong irrespective of the size of the shadow economy in steady state.

It is interesting to compare these results with the consequences of a stan-

\footnotetext{
${ }^{22}$ From (35) it is easy to see that $\widetilde{\omega}^{S} \cong \widetilde{\omega}^{o}$ when $\kappa^{s}=\kappa^{o}$.

${ }^{23}$ In the Appendix we show that $\kappa^{s}$ affects the steady state value of the shadow entrepreneurs' net wealth.

${ }^{24}$ Details of relevant simulations available upon request.
} 


\begin{tabular}{l|l|l} 
Parameter & Value & $\begin{array}{l}\text { Table 1: Parameter values } \\
\text { Description }\end{array}$ \\
\hline \hline$\beta$ & 0.99 & $\begin{array}{l}\text { Household subjective discount factor, consistent } \\
\text { with a 4\% real interest rate }\end{array}$ \\
\hline$\sigma^{o}$ & 6 & $\begin{array}{l}\text { price-elasticity of demand for a differentiated } \\
\text { good, consistent with a 20\% price mark-up }\end{array}$ \\
\hline$\sigma^{s}$ & 20 & $\begin{array}{l}\text { price-elasticity of demand for a differentiated } \\
\text { good, consistent with a 5\% price mark-up }\end{array}$ \\
\hline$\varphi^{o}$ & 4.37 & degree of price stickiness \\
\hline$\varphi^{s}$ & $4.37-2.18$ & degree of price stickiness \\
\hline$\psi$ & 2 & Inverse of Frish elasticity \\
\hline$\delta_{\pi}$ & 1 & inflation indexation parameter \\
\hline$\alpha^{o}$ & 0.36 & capital income share \\
\hline$\alpha^{s}$ & 0.28 & capital income share \\
\hline$\gamma$ & 0.02 & depreciation rate \\
\hline$\gamma$ & 0.94 & entrepreneur subjective discount factor \\
\hline$\rho^{\chi}$ & 1.5 & $\begin{array}{l}\text { elasticity of substitution between official and } \\
\text { shadow consumption bundles }\end{array}$ \\
\hline$\rho^{\theta}$ & 0.8 & financial shock autocorrelation \\
\hline$\rho^{R}$ & 0.1 & productivity shock autocorrelation \\
\hline$\phi^{\pi}$ & 1.5 & Interest rate smoothing parameter \\
\hline$\kappa^{o}$ & 0.7 & Taylor parameter \\
\hline$\kappa^{s}$ & 0 & External habit parameter \\
\hline$\chi^{o}$ & 0.1 & entrepreneur wealth dissipation parameter \\
\hline financial efficiency parameter \\
\hline financial efficiency parameter \\
\hline
\end{tabular}

Table 2: Sensitivity analysis: steady state shares of the shadow economy

\begin{tabular}{lrrrrr}
\hline & Baseline & $\sigma^{s}=\sigma^{o}$ & $\alpha^{s}=\alpha^{o}$ & $\chi^{s}=\chi^{o}$ & $k^{s}=k^{o}$ \\
\hline \hline High SH & 0.476 & 0.360 & 0.881 & 0.510 & 0.476 \\
Low SH & 0.126 & 0.095 & 0.231 & 0.137 & 0.126 \\
\hline
\end{tabular}


Table 3: Sectoral output correlations

Financial shock Productivity shock

\begin{tabular}{lll} 
High SH $=$ & -0.9935 & 0.9410 \\
Low SH $=$ & -0.9618 & 0.9690 \\
\hline
\end{tabular}

dard productivity shock in the official economy, (Figure 6). In this case we obtain an increase in official output and a fall in official employment. This well-known effect is in line with a large body of theoretical and empirical literature (Gali and Rabanal, 2004; Fernald, 2007; Canova et al., 2010). The fall in the real interest rate stimulates demand for unofficial goods, and the lower real wage allows the informal sector to increase employment. Contrary to what we observe for the credit shock, the transmission of the productivity shock is now positive. Table 3 presents sectoral correlations caused by the two different shocks.

\section{Conclusions}

Our empirical evidence suggests that the size of the shadow economy increases in the aftermath of banking crises. Our theoretical model allows us to highlight the transmission channels that might generate this result. Basically, the banking shock disrupts the formation of capital in the official economy, causing a reduction in official employment and a fall in the real wage that allows the unofficial sector to absorb more labour, thereby increasing the expected returns from unofficial capital formation.

Further research should relax the hypothesis of complete labour market integration, introducing a distinction between a formal labour market characterised by search frictions and a competitive informal labour market, as in Zenou (2008).

Another important development would be to investigate the role of fiscal policy. Empirical research should highlight whether official and unofficial outputs were affected by different choices about public debt accumulation in response to crisis episodes. Developing a fiscal sector in our theoretical model could identify which policies should be implemented in response to banking crises. 


\section{References}

Allen, Franklin, Jun Qian, and Meijun Qian, "Law, finance, and economic growth in China," Journal of Financial Economics, July 2005, 77 (1), 57-116.

_, _, Chenying Zhang, and Mengxin Zhao, "China's Financial System: Opportunities and Challenges," in "Capitalizing China" NBER Chapters, National Bureau of Economic Research, Inc, 2012, pp. 63-143.

Amaral, Pedro S. and Erwan Quintin, "A competitive model of the informal sector," Journal of Monetary Economics, October 2006, 53 (7), $1541-1553$.

Antunes, Antnio, Tiago Cavalcanti, and Anne Villamil, "The effect of financial repression and enforcement on entrepreneurship and economic development," Journal of Monetary Economics, March 2008, 55 (2), 278297.

Ayyagari, Meghana, Asli Demirg-Kunt, and Vojislav Maksimovic, "Formal versus Informal Finance: Evidence from China," Review of Financial Studies, August 2010, 23 (8), 3048-3097.

Bajada, Christopher, "Business Cycle Properties of the Legitimate and Underground Economy in Australia," The Economic Record, December 2003, 79 (247), 397-411.

- and Friedrich Schneider, "The Shadow Economies Of The AsiaPacific," Pacific Economic Review, October 2005, 10 (3), 379-401.

Banerjee, Abhijit and Esther Duflo, "The Economic Lives of the Poor," Journal of Economic Perspectives, Winter 2007, 21 (1), 141-168.

Batini, Nicoletta, Paul Levine, Emanuela Lotti, and Bo Yang, "Informality, Frictions and Monetary Policy," School of Economics Discussion Papers 0711, School of Economics, University of Surrey July 2011.

Bernanke, Ben and Mark Gertler, "Agency Costs, Net Worth, and Business Fluctuations," American Economic Review, March 1989, 79 (1), 1431 . 
Besley, Timothy and Alec Levenson, "The Role of Informal Finance in Household Capital Accumulation: Evidence from Taiwan," Economic Journal, January 1996, 106 (434), 39-59.

Bils, Mark and Jang-Ok Cho, "Cyclical factor utilization," Journal of Monetary Economics, April 1994, 33 (2), 319-354.

Bosch, Mariano and Julen Esteban-Pretel, "Job creation and job destruction in the presence of informal markets," Journal of Development Economics, 2012, 98 (2), 270-286.

Busato, Francesco and Bruno Chiarini, "Market and underground activities in a two-sector dynamic equilibrium model," Economic Theory, May 2004, 23 (4), 831-861.

Canova, Fabio, David Lopez-Salido, and Claudio Michelacci, "The effects of technology shocks on hours and output: a robustness analysis," Journal of Applied Econometrics, 2010, 25 (5), 755-773.

Carlstrom, Charles and Timothy Fuerst, "Agency Costs, Net Worth, and Business Fluctuations: A Computable General Equilibrium Analysis," American Economic Review, December 1997, 87 (5), 893-910.

Castillo, Paul and Carlos Montoro, "Monetary Policy in the presence of Informal Labour Markets," Working Papers 2010-009, Banco Central de Reserva del Per July 2010.

Cerra, Valerie and Sweta Saxena, "Growth Dynamics: The Myth of Economic Recovery," American Economic Review, March 2008, 98 (1), 439-57.

Comin, Diego and Mark Gertler, "Medium-Term Business Cycles," American Economic Review, June 2006, 96 (3), 523-551.

Conesa Roca, Juan Carlos, Carlos Daz Moreno, and Jos Enrique Galdn Snchez, "Underground economy and aggregate fluctuations," Spanish Economic Review, 2001, 3 (1), 41-53.

Conning, Jonathan and Christopher Udry, Rural Financial Markets in Developing Countries, Vol. 3 of Handbook of Agricultural Economics, Elsevier, 
Dell'Ariccia, Giovanni, Enrica Detragiache, and Raghuram Rajan, "The real effect of banking crises," Journal of Financial Intermediation, January 2008, 17 (1), 89-112.

Eilat, Yair and Clifford Zinnes, "The Shadow Economy in Transition Countries: Friend or Foe? A Policy Perspective," World Development, July 2002, 30 (7), 1233-1254.

Elgin, Ceyhun and Oguz Oztunali, "Shadow Economies around the World: Model Based Estimates," Working Papers 2012/05, Bogazici University, Department of Economics May 2012.

Feld, Lars P. and Friedrich Schneider, "Survey on the Shadow Economy and Undeclared Earnings in OECD Countries," German Economic Review, 05 2010, 11, 109-149.

Fernald, John G., "Trend breaks, long-run restrictions, and contractionary technology improvements," Journal of Monetary Economics, November 2007, 54 (8), 2467-2485.

Fiess, Norbert M., Marco Fugazza, and William Maloney, "Informal self-employment and macroeconomic fluctuations," Journal of Development Economics, March 2010, 91 (2), 211-226.

Gali, Jordi and Pau Rabanal, "Technology Shocks and Aggregate Fluctuations: How Well Does the RBS Model Fit Postwar U.S. Data?," in Mark Gertler and Kenneth Rogoff, eds., NBER Macroeconomics Annual, MIT Press, 2004.

Garmaise, Mark and Tobias Moskowitz, "Informal Financial Networks: Theory and Evidence," Review of Financial Studies, 2003, 16 (4), 10071040.

Gertler, Mark, Nobuhiro Kiyotaki, and Albert Queralto, "Financial Crises, Bank Risk Exposure and Government Financial Policy," Technical Report 740, NYU 2011.

Giles, David, "Causality between the measured and underground economies in New Zealand," Applied Economics Letters, 1997, 4 (1), 63-67. 
Granda-Carvajal, Catalina, "The Unofficial Economy and the Business Cycle: A Test for Theories," International Economic Journal, 2010, 24 (4), 573-586.

Guiso, Luigi, Paola Sapienza, and Luigi Zingales, "The Role of Social Capital in Financial Development," American Economic Review, June 2004, 94 (3), 526-556.

Hadri, Kaddour, "Testing for stationarity in heterogeneous panel data," Econometrics Journal, 2000, 3 (2), 148-161.

Im, Kyung So, M. Hashem Pesaran, and Yongcheol Shin, "Testing for unit roots in heterogeneous panels," Journal of Econometrics, July 2003, 115 (1), 53-74.

Kamada, Koichiro and Kazuto Masuda, "Effects of Measurement Error on the Output Gap in Japan," Monetary and Economic Studies, May 2001, 19 (2), 109-154.

Koreshkova, Tatyana A., "A quantitative analysis of inflation as a tax on the underground economy," Journal of Monetary Economics, May 2006, $53(4), 773-796$.

Kroszner, Randall S., Luc Laeven, and Daniela Klingebiel, "Banking crises, financial dependence, and growth," Journal of Financial Economics, April 2007, 84 (1), 187-228.

Kwiatkowski, Denis, Peter C. B. Phillips, Peter Schmidt, and Yongcheol Shin, "Testing the null hypothesis of stationarity against the alternative of a unit root: How sure are we that economic time series have a unit root?," Journal of Econometrics, 1992, 54 (1-3), 159-178.

La Porta, Rafael and Andrei Shleifer, "The Unofficial Economy and Economic Development," Brookings Papers on Economic Activity, 2008, 39 (2 (Fall)), 275-363.

Laeven, Luc and Fabian Valencia, "Systemic Banking Crises: A New Database," IMF Working Papers 08/224, International Monetary Fund September 2008 . 
_ and _, "Resolution of Banking Crises: The Good, the Bad, and the Ugly," IMF Working Papers 10/146, International Monetary Fund June 2010 .

Madestam, Andreas, "Informal Finance: A Theory of Moneylenders," Working Papers 347, IGIER (Innocenzo Gasparini Institute for Economic Research), Bocconi University 2008.

Maloney, William, "Does Informality Imply Segmentation in Urban Labor Markets? Evidence from Sectoral Transitions in Mexico," World Bank Economic Review, May 1999, 13 (2), 275-302.

_ , "Informality Revisited," World Development, July 2004, 32 (7), 11591178 .

- and Jaime Saavedra-Chanduvi, "The Informal Sector: What Is It, Why Do We Care, and How Do We Measure It?," in Guillermo Perry, Omar Arias, Pablo Fajnzylber, William Maloney, Andrew Mason, and Jaime Saavedra-Chanduvi, eds., Informality: Exit and Exclusion, 2005.

Marchetti, Domenico and Giuseppe Parigi, "Energy consumption, survey data and the prediction of industrial production in Italy: A comparison and combination of different models," Journal of Forecasting, 2000, 19 (5), 419-440.

Mattesini, Fabrizio and Lorenza Rossi, "Optimal monetary policy in economies with dual labor markets," Journal of Economic Dynamics and Control, July 2009, 33 (7), 1469-1489.

Onnis, Luisanna and Patrizio Tirelli, "Challenging the popular wisdom. New estimates of the unobserved economy," Working Papers 184, University of Milano-Bicocca, Department of Economics April 2010.

Pedroni, Peter, "Critical Values for Cointegration Tests in Heterogeneous Panels with Multiple Regressors," Oxford Bulletin of Economics and Statistics, 1999, 61 (0), 653-70.

_ , "Fully-Modified OLS for Heterogeneous Cointegrated Panels," Advances in Econometris, 2000, 15, 93-130. 
_. " "Purchasing Power Parity Tests In Cointegrated Panels," The Review of Economics and Statistics, November 2001, 83 (4), 727-731.

_, "Panel Cointegration: Asymptotic And Finite Sample Properties Of Pooled Time Series Tests With An Application To The Ppp Hypothesis," Econometric Theory, June 2004, 20 (03), 597-625.

Pesaran, M. Hashem, "A simple panel unit root test in the presence of cross-section dependence," Journal of Applied Econometrics, 2007, 22 (2), 265-312.

Pratap, Sangeeta and Erwan Quintin, "The Informal Sector in Developing Countries: Output, Assets and Employment," Working Papers RP2006/130, World Institute for Development Economic Research (UNUWIDER) 2006.

Rajan, Raghuram G and Luigi Zingales, "Financial Dependence and Growth," American Economic Review, June 1998, 88 (3), 559-86.

Reinhart, Carmen and Kenneth Rogoff, "The Aftermath of Financial Crises," American Economic Review, May 2009, 99 (2), 466-72.

_ and _, This Time Is Different. Eight Centuries of Financial Folly, Princeton University Press, 2009.

Romer, Christina D. and David H. Romer, "Does Monetary Policy Matter? A New Test in the Spirit of Friedman and Schwartz," in "NBER Macroeconomics Annual 1989, Volume 4" NBER Chapters, National Bureau of Economic Research, Inc, October 1989, pp. 121-184.

_ and _, "The Macroeconomic Effects of Tax Changes: Estimates Based on a New Measure of Fiscal Shocks," American Economic Review, June 2010, 100 (3), 763-801.

Rotemberg, Julio J, "Monopolistic Price Adjustment and Aggregate Output," Review of Economic Studies, October 1982, 49 (4), 517-31.

Russo, Francesco Flaviano, "Double Business Cycle: the Hidden Economy in the US," 2008. 
Schmitt-Grohe, Stephanie and Martin Uribe, "Optimal fiscal and monetary policy under sticky prices," Journal of Economic Theory, February $2004,114(2), 198-230$.

Schneider, Friedrich and Andreas Buehn, "Shadow Economies in Highly Developed OECD Countries: What Are the Driving Forces?," IZA Discussion Papers 6891, Institute for the Study of Labor (IZA) October 2012 .

- and Dominik H. Enste, "Shadow Economies: Size, Causes, and Consequences," Journal of Economic Literature, March 2000, 38 (1), 77-114.

_, Andreas Buehn, and Claudio E. Montenegro, "Shadow economies all over the world : new estimates for 162 countries from 1999 to 2007," Policy Research Working Paper Series 5356, The World Bank June 2010.

Straub, Stphane, "Informal sector: The credit market channel," Journal of Development Economics, December 2005, 78 (2), 299-321.

Wouters, Raf and Frank Smets, "Comparing shocks and frictions in US and euro area business cycles: a Bayesian DSGE Approach," Journal of Applied Econometrics, 2005, 20 (2), 161-183.

Zenou, Yves, "Job search and mobility in developing countries. Theory and policy implications," Journal of Development Economics, June 2008, 86 (2), 336-355. 
Table 4: Predicting banking crises

\begin{tabular}{lccc}
\hline \hline & GDP & TEM & MTEA \\
\hline $\mathrm{L}_{0}$ & $-0.060^{* * *}$ & -0.01 & -0.005 \\
& -0.02 & -0.01 & -0.01 \\
$\mathrm{~L}_{1}$ & -0.01 & -0.015 & -0.006 \\
& -0.02 & -0.01 & -0.01 \\
$\mathrm{~L}_{2}$ & -0.015 & -0.01 & -0.006 \\
& -0.02 & -0.01 & -0.01 \\
$\mathrm{~L}_{3}$ & 0.012 & -0.005 & -0.007 \\
& -0.02 & -0.01 & -0.01 \\
$\mathrm{~L}_{4}$ & 0.009 & -0.003 & -0.004 \\
& -0.02 & -0.01 & -0.01 \\
$\mathrm{~N}$. Obs & 2788 & 2541 & 2541 \\
$\mathrm{~N}$. of Count. & 120 & 120 & 120 \\
\hline
\end{tabular}

Note: Dependent variable is dummy for banking crisis, regressors are official GDP growth (col 1), Total Economic Activity growth TEA (col 2), Total Economic Activity growth MTEA ( $\mathrm{Col} 3) . \mathrm{L}_{0} \ldots \mathrm{L}_{4}$ denote regressors at lag 0 to 4 . Estimation is panel logit random effect. Robust standard errors reported in parentheses. $* * *, * *, *$ denote significance at the 1,5 and 10 percent levels respectively. 
Figure 1: Impulse responses to financial crises, cumulated losses. GDP and total economic activity (electricity consumption); overall and country groups.
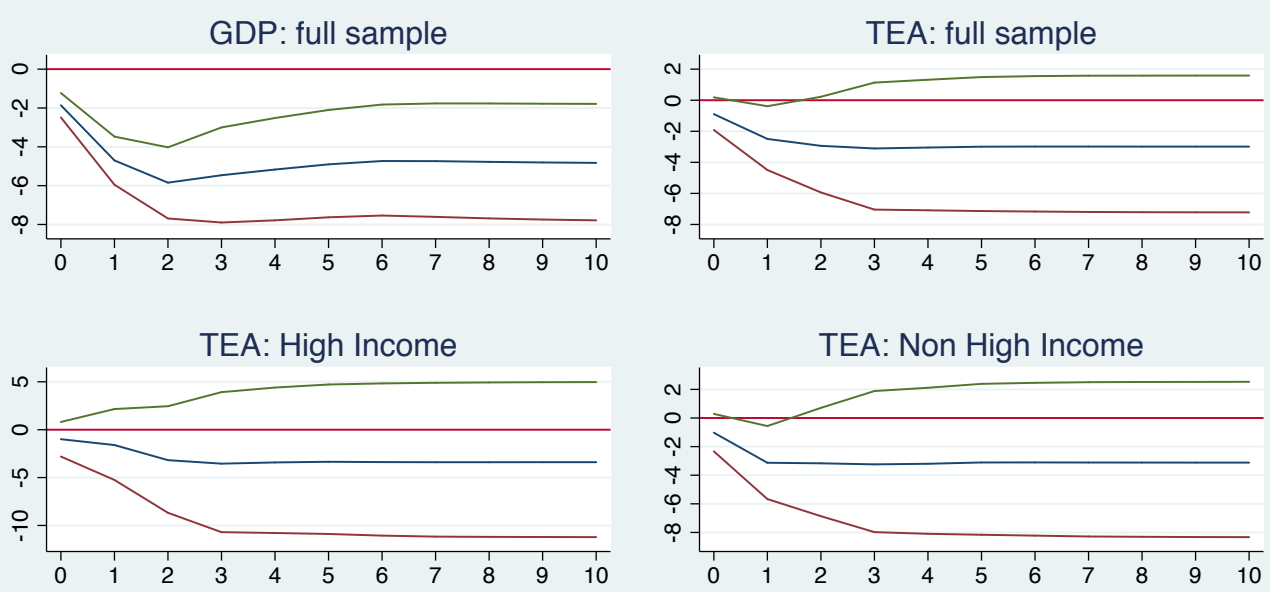

TEA: Middle Income

TEA: Low Income
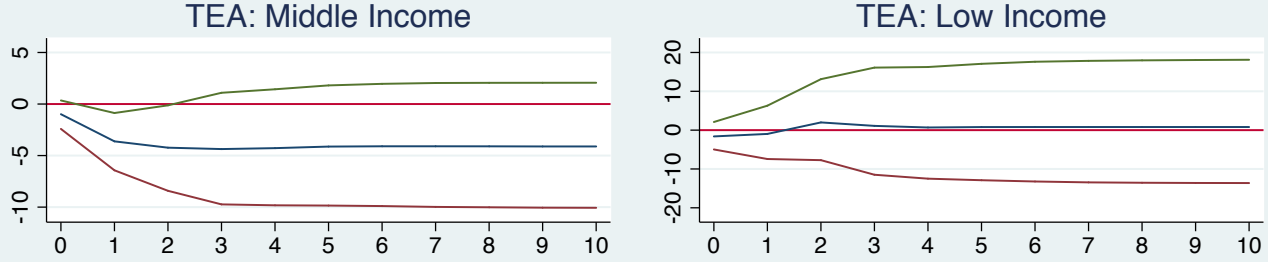
Figure 2: Impulse responses to financial crises, cumulated losses. GDP and total economic activity (modified electricity consumption); overall and country groups.
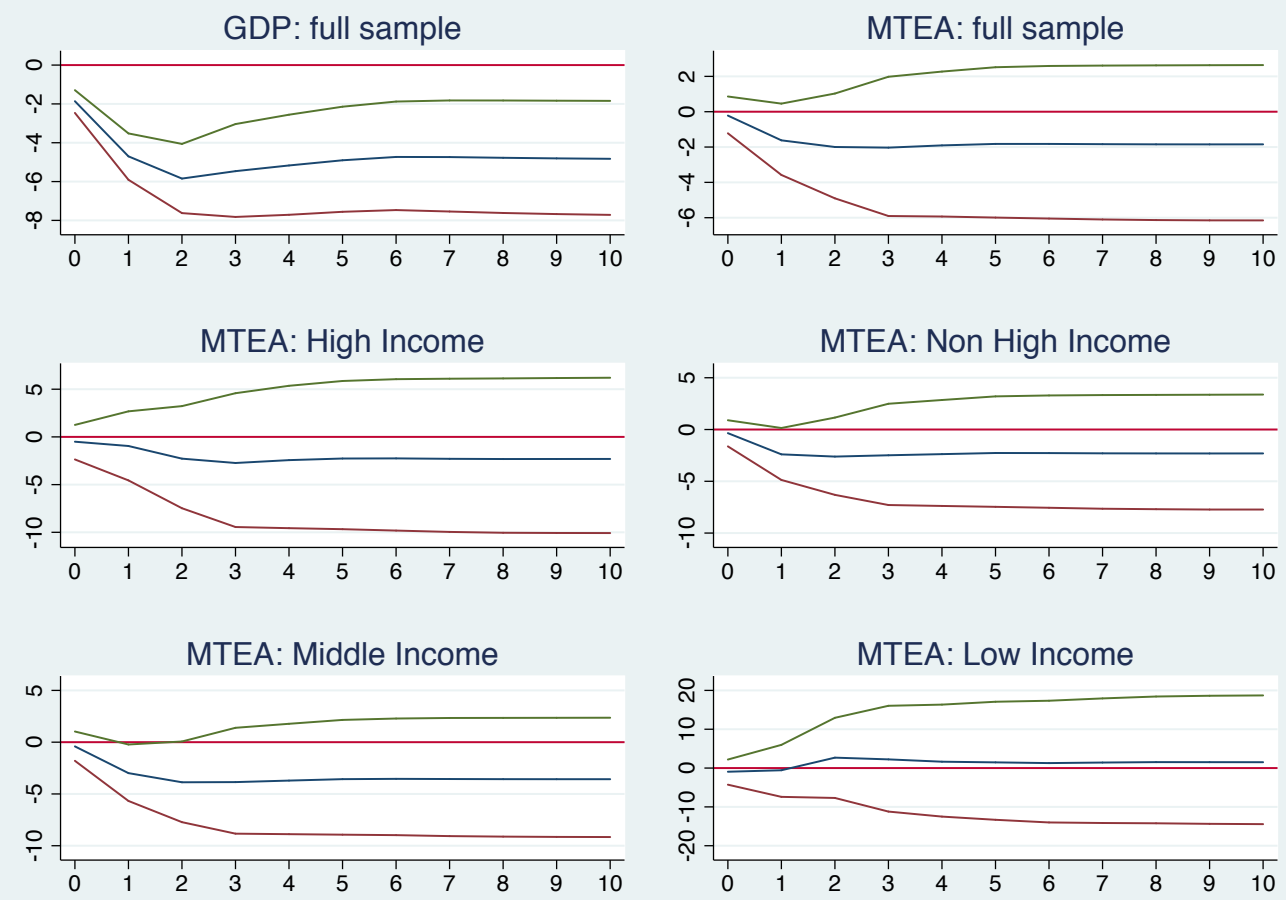
Figure 3: Impulse responses to financial crises, cumulated losses. Total economic activity; robustness checks

TEA

\section{MTEA}

Time dummies
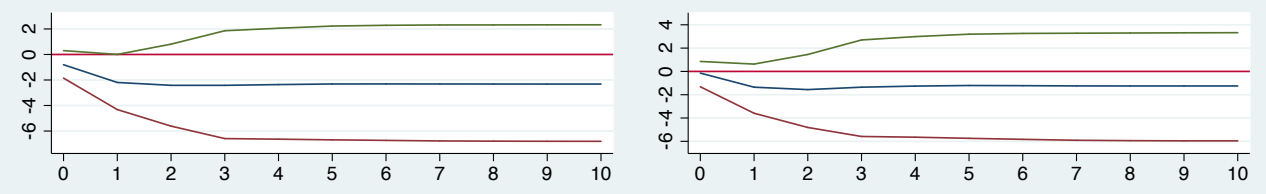

No outliers
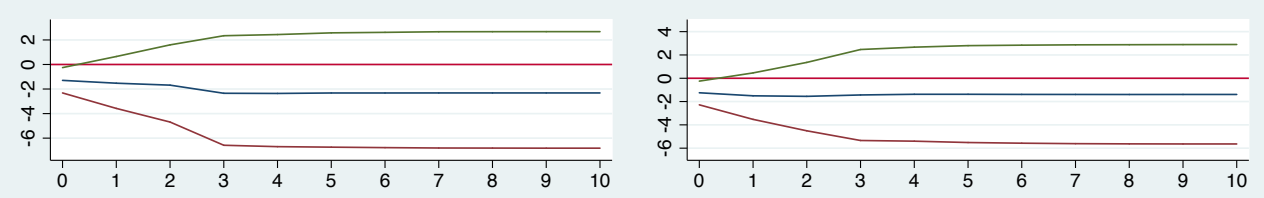

No contemporaneous effect
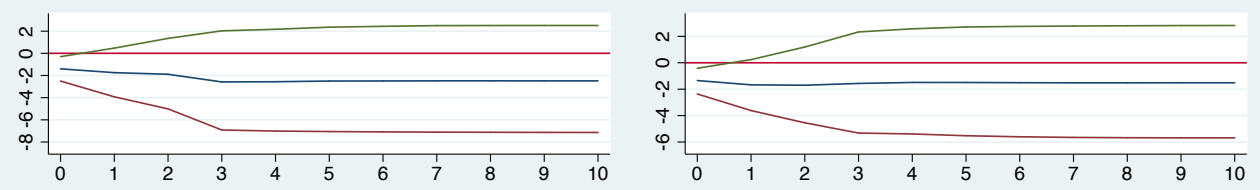
Figure 4: Impulse responses to a financial shock. Low share of the shadow economy
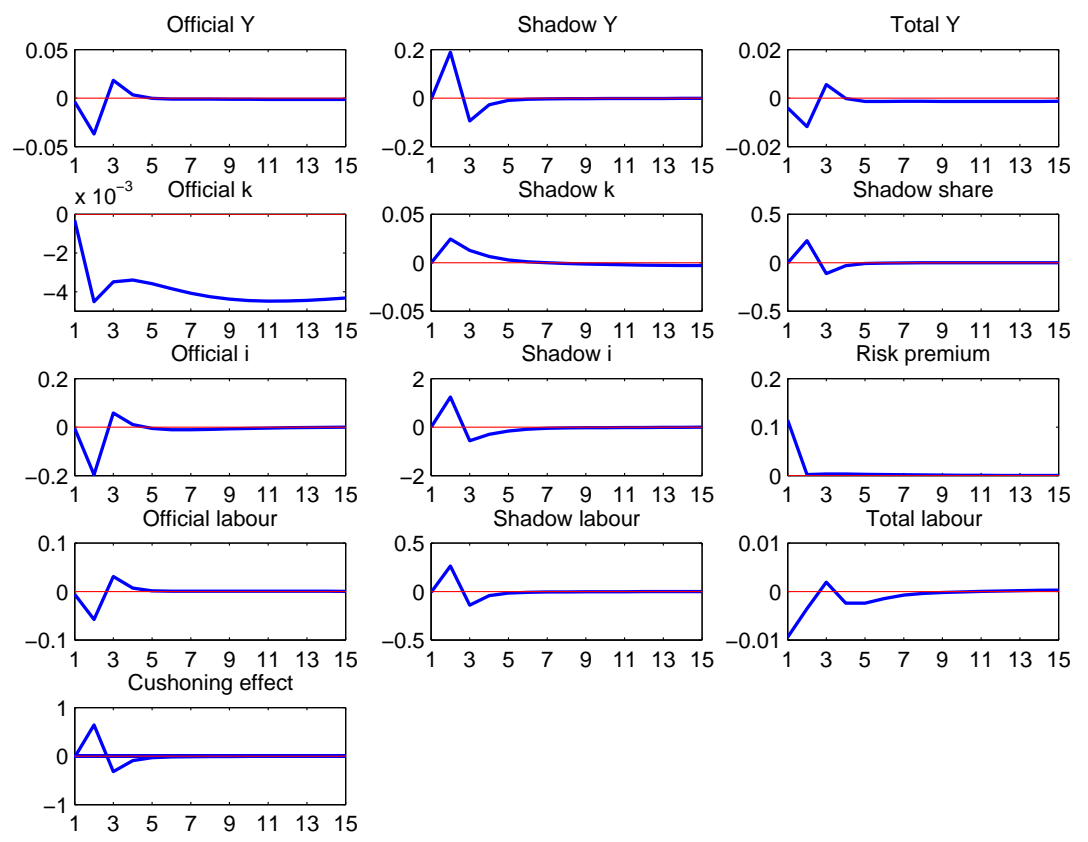
Figure 5: Impulse responses to a financial shock. High share of the shadow economy
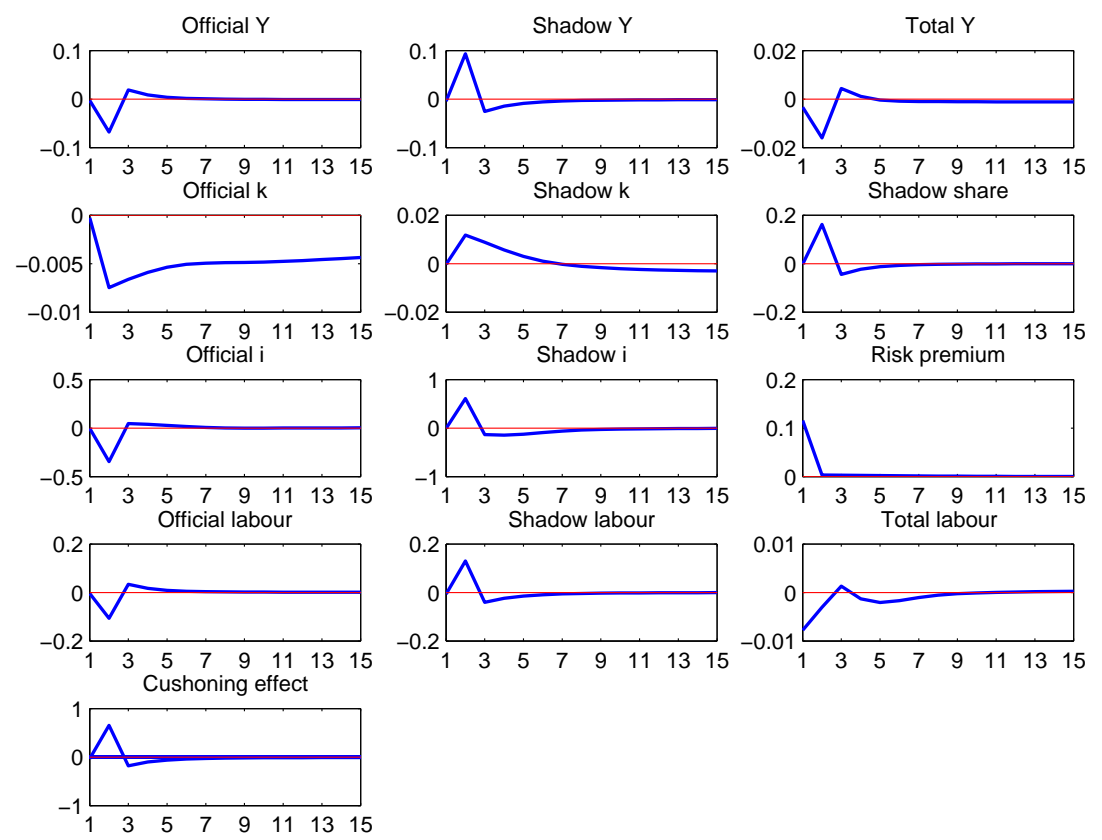
Figure 6: Impulse responses to a productivity shock.
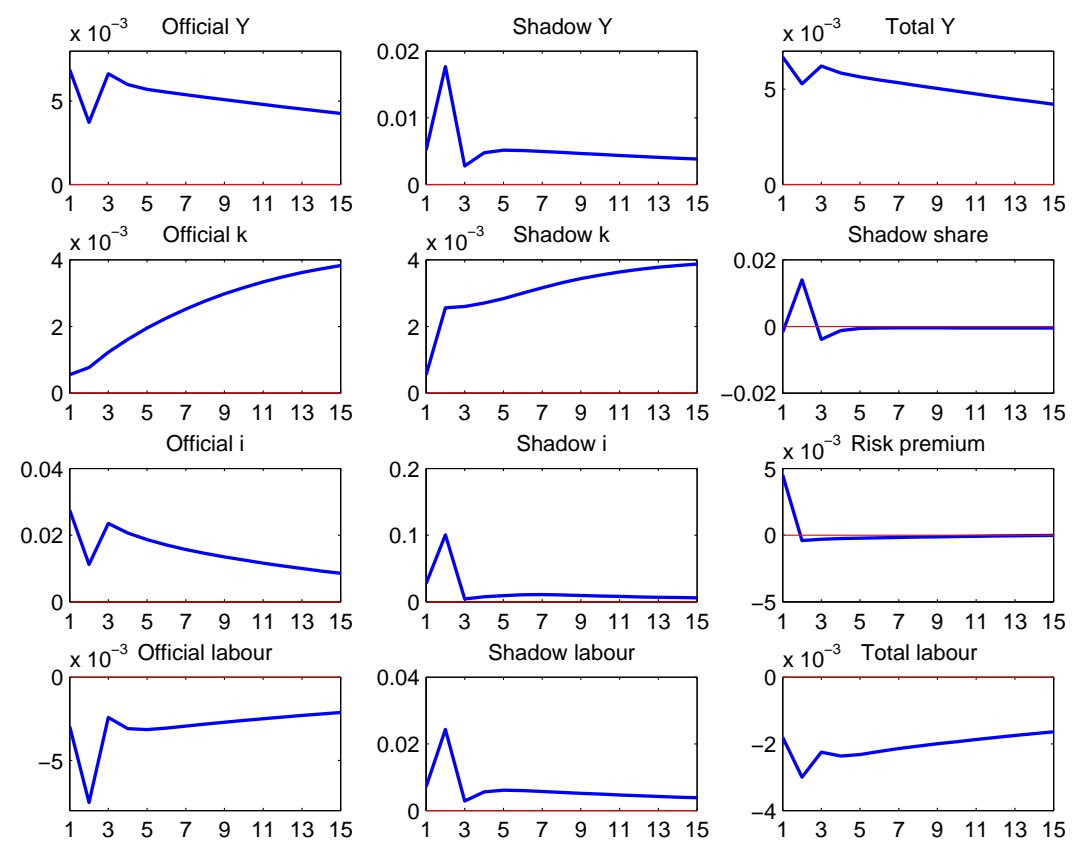


\section{Appendix}

\subsection{Estimates for Total Economic Activity}

Data on electricity consumption, real price of electricity, share of industrial income and official GDP have been obtained from Energy Information Administration, International Energy Agency, World Bank and United Nations, respectively.

Approximating the growth of total economic activity by means of electricity consumption growth is a straightforward exercise. in the following we outline the method used to obtain $M T E A g$, which is akin to (Eilat and Zinnes, 2002; Onnis and Tirelli, 2010). Our analysis is based on the assumption that changes in the domestic real price of electricity capture the effects of supply shocks and of long term efficiency gains caused by technical change, whereas changes in the industry share of GDP affect the component of electricity consumption which is directly related to the country-specific evolution in the composition of domestic output. The first stage of our application of the MTE procedure is therefore based on the following equation:

$$
\Delta \text { Elec }_{i, t}=\alpha_{i}+\beta_{1} \Delta \text { Eprice }_{i, t}+\beta_{2} \Delta \operatorname{IndGdp} p_{i, t}+\varepsilon_{i, t}
$$

where subscripts $t, i$ are time and country indexes, $\Delta$ Elec, $\Delta$ Eprice and $\Delta I n d G d p$ respectively describe annual percentage changes in electricity consumption, in the real price of electricity and in the industry share of GDP.

Once the relative-price and demand-composition effects have been identified, the residual changes in electricity consumption, $\Delta E l e c^{r e s}$, may be used as a proxy for the growth rate in total economic activity $(M T E A g)$ :

$$
\Delta \text { Elec }_{i, t}^{\text {res }}=\Delta \text { Elec }_{i, t}-\left[\beta_{1} \Delta \text { Eprice }_{i, t}+\beta_{2} \Delta \operatorname{IndGdp_{i,t}]}\right.
$$

Since the time series dimension of the panel is relatively long, the econometric methodology is based on a preliminary stationarity and cointegration analysis of the relevant variables. Variables $\Delta$ Elec, $\Delta$ Eprice, $\Delta$ IndGdp exhibit non stationarity, tested using Im et al. (2003), Pesaran (2007), Hadri (2000), Kwiatkowski et al. (1992), ADF and Phillips-Perron unit root tests. A cointegrating relationships between $\Delta$ Elec, $\Delta$ Eprice and $\Delta I n d G d p$ has been, therefore, detected using the residual-based procedure developed by Pedroni (1999), Pedroni (2004). 
Due to the presence of cointegrated time series, in our estimate of equation (33) we use the group-mean panel Fully Modified Ordinary Least Squares (FMOLS) method proposed by Pedroni (2000), Pedroni (2001). The groupFMOLS estimates reported in Onnis and Tirelli (2010) suggest that a positive and statistically significant relationship exists between the changes in electric consumption and those in the share of industry. On the contrary, a negative and statistically significant relationship exists between the changes in electric consumption and those in electricity price. ${ }^{25}$

\subsection{Computation of impulse response functions}

Impulse responses have been calculated as follows. First we have estimated equation (1) by GLS with fixed effects and time dummies. Obtained the estimated coefficients we have assumed that they are drawn from a multivariate normal distribution with mean the estimated vector of coefficients and as variance the estimated variance covariance matrix.

We have drawn a sample of 1000 coefficients from the distribution and we have simulated the cumulative effect of a financial crises. Confidence intervals have been calculated from the 2.5 and 97.5 percentiles.

\subsection{Steady state derivation}

¿From (15) (22) (24) we obtain

$$
\widetilde{\omega}^{j}=(\bar{\omega}-\underline{\omega})-\frac{\mu^{j}}{1-\left(1-\kappa^{j}\right) \gamma}
$$

this allows to obtain $f\left(\widetilde{\omega}^{j}\right), g\left(\widetilde{\omega}^{j}\right)$ from (16) (17) (18) (19). Then from (15) (24) we get the relative price of capital in the official economy

\footnotetext{
${ }^{25}$ To use changes in country-specific electricity price as an explanatory variable for changes in electricity consumption may generate problems of endogeneity. Firstly, we have re-estimated equation (33) adopting an alternative more exogenous real price of energy for 26 OECD countries and a global index of energy price for the remaining 23 countries. Second, we have used the global price of energy for the entire panel. In both situations we have obtained the same result. There is a positive and statistically significant relationship between changes in electricity consumption and changes in industry share of GDP. There is a negative and statistically significant relationship between changes in electricity usage and changes in the price of energy.
} 


$$
q^{o}=\frac{1}{\left(f\left(\widetilde{\omega}^{o}\right) \gamma+g\left(\widetilde{\omega}^{o}\right)\right)}
$$

From (25) and (26) we get the the relative price of capital in the unofficial economy

$$
\frac{q^{s}}{q^{o}}=\frac{\left(1-\kappa^{o}\right) f\left(\widetilde{\omega}^{o}\right)}{\left(1-\kappa^{s}\right) f\left(\widetilde{\omega}^{s}\right)}
$$

Note that $\frac{q^{s}}{q^{o}}$ is entirely determined by those parameters that characterize the relative financial markets imperfections in the shadow economy, $\kappa^{j} \chi^{j} \mu^{j}$. In our benchmark calibrations we obtain $\frac{q^{s}}{q^{o}}=$. When we set $\chi^{s}=\chi^{o}$ and $\kappa^{s}=\kappa^{o}$ we obtain so that that the relative sectoral capital price amounts to 1.01 .

¿From (15) we obtain the sectoral real return on capital.

$$
r^{j}=q^{j}\left(\frac{1}{\beta}-(1-\delta)\right)
$$

This also shows that the relative sectoral marginal productivity of capital is equal to the relative price of capital and is therefore explained by the same factors.

¿From (6) we get the implied capital-labor ratios in the two sectors which obviously increase in $\alpha^{j}$.

$$
\left(\frac{k^{j}}{h^{j}}\right)=\left(\frac{r^{j}}{\alpha^{j}}\right)^{-\frac{1}{\left(1-\alpha^{j}\right)}}
$$

From (32) we obtain that $\pi^{o}=1$. Steady state equilibrium therefore implies that $\pi^{s}=1$. From (8) and (11) we get the solution for relative prices, which are determined by financial factors, relative markups and the technology parameters.

$$
\frac{P^{R o}}{P^{R s}}=\frac{\frac{\sigma^{o}}{\sigma^{o}-1}\left(\frac{r^{o}}{\alpha^{o}}\right)^{\frac{\alpha^{o}}{1-\alpha^{o}}}}{\frac{\sigma^{s}}{\sigma^{s}-1}\left(\frac{r^{s}}{\alpha^{s}}\right)^{\frac{\alpha^{s}}{1-\alpha^{s}}}}\left(\frac{\left(1-\alpha^{s}\right)}{\left(1-\alpha^{o}\right)}\right)
$$

Using (4) we obtain

$$
\left(\frac{P}{P^{R s}}\right)=\left((1-\alpha)\left(\frac{P^{R o}}{P^{R s}}\right)^{(1-\varepsilon)}+\alpha\right)^{\frac{1}{(1-\varepsilon)}}
$$


Then from (5) we get the solution for the real wage.

$$
w=\left(1-\alpha^{s}\right)\left(\frac{k_{t}^{s}}{h_{t}^{s}}\right)^{\alpha^{s}}\left(\frac{P^{R s}}{P}\right)
$$

and for the relative retail price of official goods

$$
\left(\frac{P^{R o}}{P}\right)=\frac{w}{\left(1-\alpha^{o}\right)}\left(\frac{k^{o}}{h^{o}}\right)^{-\alpha^{o}}
$$

Now from $(27)$ we get $k_{t}^{j}=(1-\delta) k_{t-1}^{j}+\eta \eta^{j} i_{t}^{j}\left(1-\phi\left(\widetilde{\omega}_{t}^{j}-\underline{\omega}\right) \mu^{j}-\chi_{t}^{j}\right)$

$$
\frac{i^{j}}{y^{j}}=\frac{\delta}{\eta \eta^{j}\left(1-\phi\left(\widetilde{\omega}^{j}-\underline{\omega}\right) \mu_{1}^{j}-\chi^{j}\right)}\left(\frac{k^{j}}{h^{j}}\right)^{1-\alpha^{j}}
$$

Thus, from (29) we get the solution for the unofficial economy relative size, $S H=\frac{y^{s}}{y^{o}}$

$$
\begin{gathered}
S H=\frac{\alpha_{c}}{\left(1-\alpha_{c}\right)}\left(\frac{P^{R s}}{P^{R o}}\right)^{-\varepsilon} \frac{\left(1-\frac{i^{o}}{y^{o}}\right)}{\left(1-\frac{i^{s}}{y^{s}}\right)}= \\
=\frac{\alpha_{c}}{\left(1-\alpha_{c}\right)}\left(\frac{\frac{\sigma^{o}}{\sigma^{o}-1}\left(\frac{q^{o}\left(\frac{1}{\beta}-(1-\delta)\right)}{\alpha^{o}}\right)^{\frac{\alpha^{o}}{1-\alpha^{o}}}}{\frac{\sigma^{s}}{\sigma^{s}-1}\left(\frac{q^{s}\left(\frac{1}{\beta}-(1-\delta)\right)}{\alpha^{s}}\right)^{\frac{\alpha^{s}}{1-\alpha^{s}}}}\left(\frac{\left(1-\alpha^{s}\right)}{\left(1-\alpha^{o}\right)}\right)\right)^{\varepsilon} \frac{\left(1-\frac{\delta}{\left(1-\phi\left(\widetilde{\omega}^{o}-\underline{\omega}\right) \mu^{o}-\chi^{o}\right)}\left(\frac{q^{o}\left(\frac{1}{\beta}-(1-\delta)\right)}{\alpha^{o}}\right)\right)}{\left(1-\frac{\delta}{\left(1-\phi\left(\widetilde{\omega}^{s}-\underline{\omega}\right) \mu^{s}-\chi^{s}\right)}\left(\frac{q^{s}\left(\frac{1}{\beta}-(1-\delta)\right)}{\alpha^{s}}\right)\right)}
\end{gathered}
$$

To complete the derivation of the steady state bear in mind that

$$
h^{s}=\left(\frac{k^{s}}{h^{s}}\right)^{-\alpha^{s}} y^{s}=\left(\frac{k^{s}}{h^{s}}\right)^{-}(S H) y^{o}, h^{o}=\left(\frac{k^{o}}{h^{o}}\right)^{-\alpha} y^{o}
$$

From the aggregate labour resource constraint, where we have imposed that total labor supply $h=1$ (we calibrate $\Gamma$ to obtain this) we obtain the solution for $y^{o}, y^{s}, i^{j}, n^{j}, h^{j}, c^{e j}, c$

$$
\left(\left(\frac{k^{s}}{h^{s}}\right)^{-\alpha^{s}}(S H)+\left(\frac{k^{o}}{h^{o}}\right)^{-\alpha^{o}}\right) y^{o}=1-\eta
$$




$$
\begin{gathered}
y^{s}=(S H) y^{o} \\
i^{j}=\frac{\delta}{\eta \eta^{j}\left(1-\phi\left(\widetilde{\omega}^{j}-\underline{\omega}\right) \mu^{j}-\chi^{j}\right)}\left(\frac{k^{j}}{h^{j}}\right)^{1-\alpha j} y^{j} \\
c^{j}=y^{j}-i^{j} \\
n^{j}=i^{j} \frac{\left(1-q^{j} g\left(\widetilde{\omega}^{j}\right)\right)}{1-k^{j}} \\
h^{j}=\left(\frac{k^{j}}{h^{j}}\right)^{-\alpha^{j}} y^{j} \\
c^{e j}=\left(\frac{1}{\beta \gamma}-1\right) n^{j} \\
y^{s}=\alpha_{c}\left(\frac{P^{s}}{P}\right)^{-\varepsilon}\left((1-\eta) c+\eta\left(\left(1-\eta^{o}\right) c^{e s}+\eta^{o} c^{e o}\right)\right)+\eta\left(1-\eta^{o}\right)\left(i^{s}\right)
\end{gathered}
$$

